\title{
Effect of Transportation on Body Weight and Hematology in Goats
}

\author{
B.N. Ambore*, S. Maini, V.R. Patodkar and S.T. Borikar \\ Department of Veterinary Clinical Medicine, Ethics \& Jurisprudence \\ KNP College of Veterinary Science, MAFSU, Shirwal - 412 801, Maharashtra, India \\ *Corresponding author
}

\begin{tabular}{|l|}
\hline K e y w o r d s \\
Transportation \\
stress, Goats, Body \\
weight, \\
Haematology \\
\hline Article Info \\
\hline $\begin{array}{l}\text { Accepted: } \\
\text { 10 June } 2019 \\
\text { Available Online: } \\
\text { 10 July } 2019\end{array}$ \\
\hline \hline
\end{tabular}

\section{Introduction}

Stress is a common factor responsible for various physio-chemical alterations in the body that indirectly insults the immune system leading to immunosuppression, decreased endurance and increased susceptibility to infections which ultimately causes the lower productivity, poor fertility, poor quality and quantity of semen and overall economic losses to the farmers.

In animals, stress may be due to overcrowding, production / lactation, weaning, transportation, environmental changes etc. Among these, transportation \& environmental stress is more common in goats. Apart from a long distance traveling for grazing, goats are frequently transported to the markets for their sale/purchase which causes enormous stress to them leading to low production. Physiological measures indicate that long transport of cattle can result in immune suppression, which can lead to increased susceptibility to disease and might result in increased pathogen shedding (Nielsen et al., 2011). During transportation the physiological insults primarily includes electrolyte imbalance, energy deficit and related catabolism and dehydration accompanying the stress. Therefore, the present investigation was carried out to know 
the effect of transportation on body weight and haematological changes in goats.

\section{Materials and Methods}

The present study was conducted in 12 Osmanabadi goats (average age of 3 years) with average body weight of $21.79 \mathrm{~kg}$. These goats were marked with identification numbers and divided into 2 different groups as shown in table 1. Animals in Group I served as negative control and was kept in complete environmental ambience, confined in a room where cooling was done with fans and water soaked gunny bags so as to maintain normal room temperature. Group II as a positive control, subjected to normal environment but subjected to transportation stress by transporting them for $12 \mathrm{hrs}$ over a distance of about $350 \mathrm{~km}$., on $10^{\text {th }}$ day of experiment. During the journey all the animals were held without feed and water. Before (Preload) and after (Post load) the transportation the goats were weighed to assess the weight loss during the journey and also weighed after 5 days of journey to observe the regain of body weight. The blood samples were collected from jugular vein thrice during the whole experiment on $5^{\text {th }}, 10^{\text {th }}$ day i.e. immediately within one hour of transportation and on $15^{\text {th }}$ day of experiment or 5 days of transportation and haematological analysis Viz. Hb, PCV, TEC, TLC and DLC was carried out (Jain, 1986).

\section{Results and Discussion}

\section{Live weight}

In both the groups increase in body weight was found during the first 5 days of experiment indicating that animals had became adapted to the conditions. The goats transported for $12 \mathrm{hrs}$ over a distance of about $350 \mathrm{Km}$ on $10^{\text {th }}$ day of experiment revealed significant decrease in the live body weight than their preload weight. After transportation average 5.76 per cent shrinkage of the body weight was observed in the positive control group II (Fig. 1).

\section{Physiological responses}

In the present study there was significant $(\mathrm{P}<$ $0.01)$ increase in the heart rate $(105 \pm 3.00 \mathrm{Vs}$ $86.30 \pm 2.03)$ before and after transportation. The significant increase in respiration rate $(43.70 \pm 3.03)$ was observed after transportation as compared to preload (29.70 $\pm 2.50)$ in positive control group. The significant difference $(\mathrm{P}<0.01)$ in temperature $(104.23 \pm 0.35 \mathrm{Vs} 102.22 \pm 0.26)$ was recorded in post and pre- transportation respectively.

Table.1 Experimental design

\begin{tabular}{|c|c|c|c|c|}
\hline Group & Treatment & $\begin{array}{c}\text { Day of } \\
\text { Transportation }\end{array}$ & $\begin{array}{c}\text { No. of } \\
\text { animals } \\
\text { /group }\end{array}$ & $\begin{array}{c}\text { Laboratory } \\
\text { Analysis }\end{array}$ \\
\hline $\begin{array}{c}\text { Negative } \\
\text { Control } \\
\text { Group - I }\end{array}$ & $\begin{array}{c}\text { Not subjected to transportation } \\
\text { stress \& kept in environmental } \\
\text { ambience }\end{array}$ & ---- & 6 & $\begin{array}{c}\text { On day } 5^{\text {th }} \\
11^{\text {th }}, 15^{\text {th }}\end{array}$ \\
\hline $\begin{array}{c}\text { Positive } \\
\text { Control } \\
\text { Group - II }\end{array}$ & $\begin{array}{c}\text { Subjected to transportation stress \& } \\
\text { environmental stress }\end{array}$ & $\begin{array}{c}10^{\text {th }} \\
\text { for } 12 \text { hrs over } 350 \mathrm{Km}\end{array}$ & 6 & $\begin{array}{c}\text { On day } 5^{\text {th }} \\
11^{\text {th }}, 15^{\text {th }}\end{array}$ \\
\hline
\end{tabular}


Fig.1 Mean body weight in goats before (BT), after (AT) and 5 days of transportation.

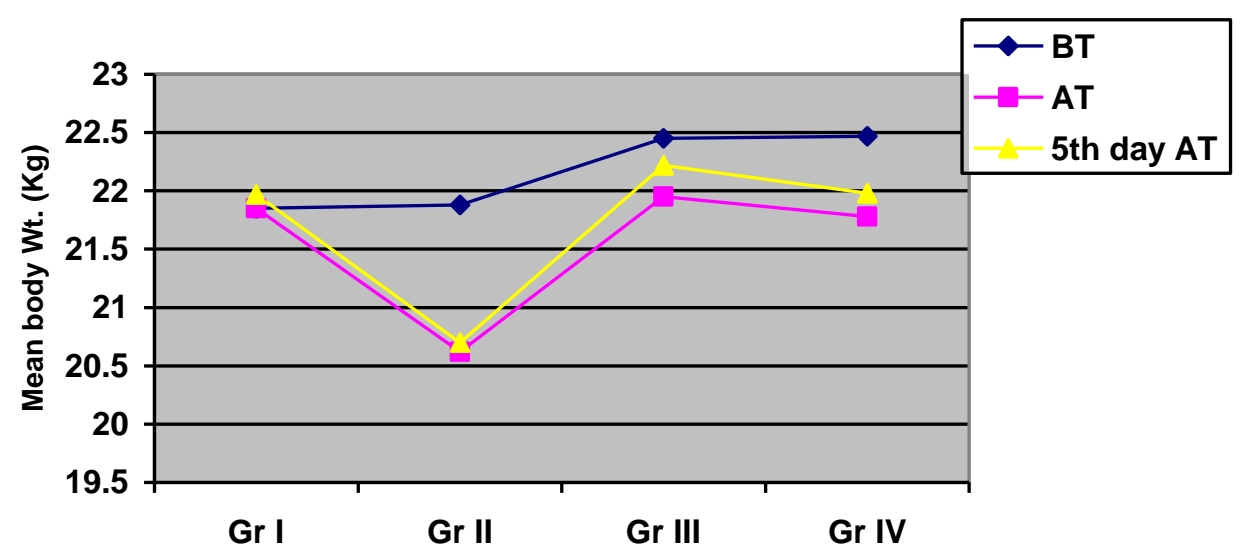

Fig.2 Mean haematological values in positive control group of goats transported

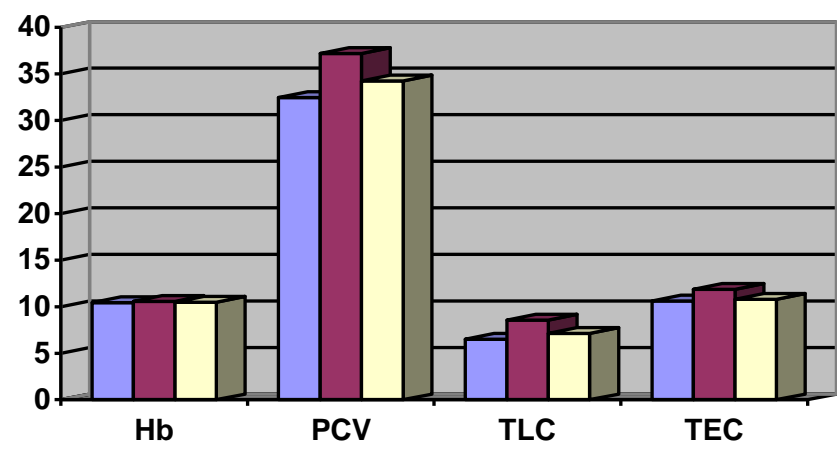

$\square \mathrm{BT}$
$\square \mathrm{AT}$
$\square$ 5th day AT

Fig.3 Per cent Neutrophils in goats before (BT), after (AT) and 5 days of transportation

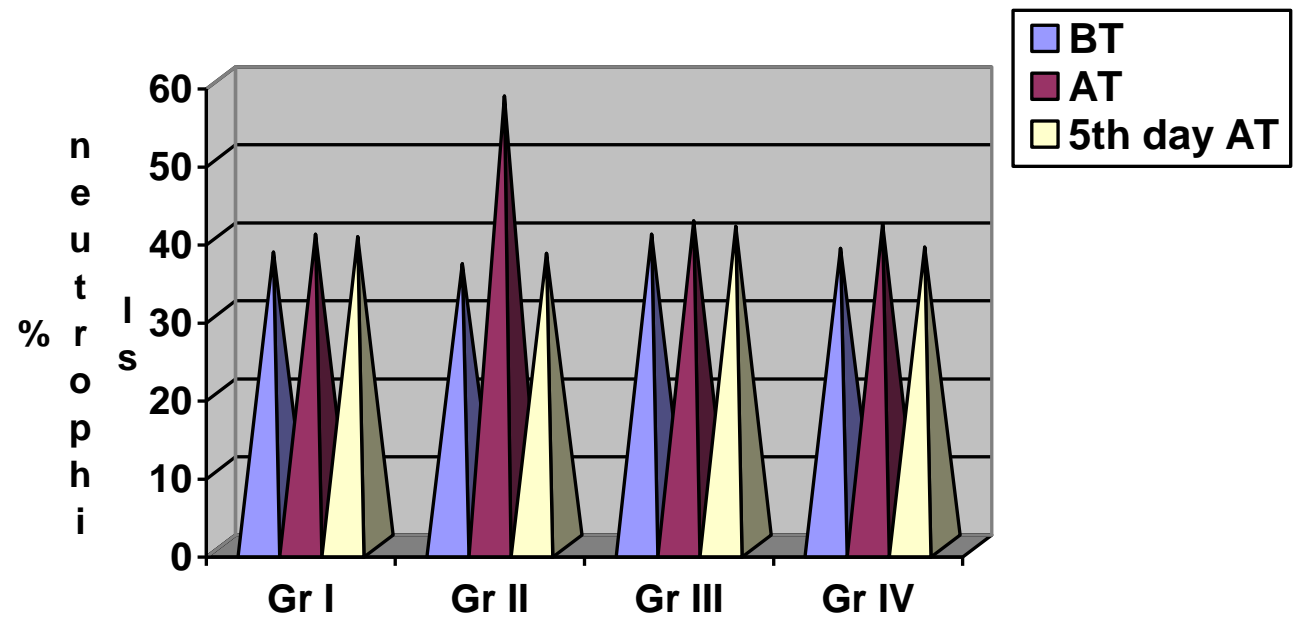




\section{Haematology}

In the present study the haematocrit values were significantly $(\mathrm{P}<0.01)$ increased from a mean of $32.48 \%$ to $37.20 \%$ in goats transported for $12 \mathrm{hrs}$. The total leukocyte count was found to be increased in all the transported groups (Fig. 2). The differential leukocyte count revealed significant $(\mathrm{P}<$ $0.01)$ increase in neutrophil per cent and decrease in the eosinophils (Fig. 3) in the goats of positive control group as compared to negative control group.

There was steady loss of live weight in sheep transported for $15 \mathrm{hrs}$ and loss in the weight was approximately 8 per cent than the pretransport weight, the loss of live weight was also found in lambs transported for $24 \mathrm{hrs}$ (Knowles et al., 1995). The rate of live weight loss reported in the literature varies widely (Warriss, 1990). In cattle during the first 24 hrs of transportation approximately 3 to 11 per cent losses of initial body weight have been reported. Most of the losses occur in the first $24 \mathrm{hrs}$ of deprivation with the greatest rate occurring during the first $12 \mathrm{hrs}$ (Knowles, 1999). The transportation can involve extended periods without food and water and as a consequence there is an initial loss of live weight, predominantly due to loss of gut fill. Approximately 7 per cent loss of body weight in ruminants and 4 per cent in pigs has been recorded during the first $18-24$ hrs of transportation (Knowles and Warriss, 2007). Wythes and Morris (1994) found average live weight losses of $3,5,7.5,11,12$ and 14 per cent over $6,12,24,48,72$ and 96 hrs respectively with food withdrawal alone, and losses as high as 20 per cent after just 72 hrs have been reported by Horton et al., (1996) when animals also deprived of water. All these findings indicate that during transportation holding of food and water is the predominant cause for the loss in body weight.
After transportation stress as the pituitary and adrenal axis get activated resulting in increase in the physiological responses i.e. heart, respiration rates and body temperature (Knowles, 1999). Glucocorticoid hormones produced in and released from the cortex of the adrenal gland in response to an extremely wide range of stimuli/stressors, play a major role in mediating the physiological responses (Knowles and Warriss, 2007).

Increase in PCV was also observed by Fenwick and Green (1986), Jacobsen et al., (1993) in response to stress of transportation and handling. Knowles et al., (1999) were also reported the increased PCV from a mean of $37.30 \%$ to $40.50 \%$ during the first $12 \mathrm{hrs}$. of the recovery period of transported cattle. Increase in PCV reflects both a splenic response to stress and dehydration. An increase in PCV can indicate dehydration but may also be due the release of erythrocytes into the circulation as a result of sympathoadrenal stimuli causing contraction of spleen (Knowles et al., 1995).

The differential leukocyte count revealed significant $(P<0.01)$ increase in neutrophil per cent and decrease in the eosinophils (Fig. 3 ) in the goats of positive control group as compared to negative control group. The present findings corroborates with the findings of Kent and Ewbank (1983) and Tarrant et al., (1992) who were also reported an increase in the number of white blood cells and neutrophil and decrease in the number of lymphocytes, eosinophils and monocytes. Leukocytosis and neutrophilia accompanied by a reduction in $\mathrm{T}$ lymphocytes and blastogenesis were observed in the transported dairy cows (Wegner et al., 1974; Schaefer et al., 1997). Kannan et al., (2000) were also reported an increased percentage of neutrophils and decreased lymphocytes due to transportation stress and the N:L ratios were higher at all time periods after transportation 
than prior to the beginning of transportation of goats. These responses in general may be cortisol driven. Excessive cortisol level in the blood during stress causes reduction in circulating lymphocytes and increase in number of neutrophils, thus altering the normal neutrophil v/s lymphocyte ratio. There were no significant $(P>0.05)$ changes in TEC were observed in goats before and after their transportation in both the groups.

It is concluded that the findings in this study suggest that the transportation was stressful to the goats and they should be fed with antistress supplements immediately after transportation to avoid further losses.

\section{References}

Fenwick, D. C. and Green, D. J. 1986. The effects of handling procedures, breed differences and treatment with Lithium and dexamethasone on some blood parameters in sheep. Appl. Anim. Behav. Sci. 16: 39.

Horton, G. M. J., Baldwin, J. A., Emanuele, S. M., Wohlt, J. E. and McDowell, L. R. 1996. Performance and blood chemistry in lambs following fasting and transport. Animal Science 52: 49-56.

Jacobsen, T., Schaefer, A. L., Tong, A. K. W; Stanley, R. K., Jones, S. D. M.,. Robertson, W. M. and Dyck, R. 1993. The effect of transport on carcass yield, meat quality and haematology values in electrolyte treated cattle. In Cong. Meat Sci. Technol Calgary, Alberta, Aug, 1 6. Paper 52 p 11 WP.

Jain, N. C. 1986. Scham's Veterinary Haematology, $4^{\text {th }}$ edn., Lea and Febiger, Philadelphia.

Kannan, G., Terrill, T. H., Kouakou, B., Gazal, O. S., Gelaye, S., Amoah, E. A. and Samake, S. 2000. Transportation of goats: Effect on physiological stress responses and live weight. J. Anim. Sci., 78: $1450-1457$.
Kent, J. K. and Ewbank, R. 1983. The effect of road transportation on blood constituents and behaviour of calves. I. six month old. Br. Vet. J. 139: 228 235.

Knowles, T. G. 1999. A review of road transport of cattle. Veterinary Record 144: 197-201

Knowles, T. G., Brown, S. N., Warriss, P. D., Philips, A. J; Dolan, S. K., Hunt, P., Ford, J. E., Edward, P. E. and Watkins, P. E. 1995. Effect on sheep of transport by road for up to 24 hours. Veterinary Record, 136: 431 - 438.

Knowles, T. G., Warriss, P. D., Brown, S. N. and Edwards, J. E. 1999. Effect on cattle of transportation by road for up to 31 hours. Veterinary Record 144: 575 582.

Knowles T. and Warriss P. 2007. Stress physiology of animals during transport. Livestock Handling and Transport $3^{\text {rd }}$ edn (ed. Grandin, T.): 312 - 328.

Nielsen B.L., Dybkjær L. and Herskin, M.S. 2011. Road transport of farm animals: effects of journey duration on animal welfare. Animal 5 (3): 415-427.

Schaefer, A. L., Jones, S.D.M. and Stanley, R. W. 1997. The use of electrolyte solutions for reducing transport stress. J. Anim. Sci., 75: 258 - 265.

Tarrant, P. V., Kenny, F. J., Harrington, D. and Murphy, P. 1992. Long distance transportation of steers to slaughter, effect of stocking density on physiology, behaviour and carcass quality. Livest. Prod. Sci. 30: 223 - 238.

Warriss, P. D. 1990. The handling of cattle pre-slaughter and its effect on carcass meat quality. Applied Animal Behaviour Science, 28: 171 - 188.

Wegner, T.N., Schuh, J.D., Nelson, F.E. and Stott, G.H. 1974. Effect of stress on blood leukocyte and milk somatic cell count in dairy cows. J. dairy Sci. 59: 949. 
Wythes, J.R. and Morris, D. G. 1994. Literature review of welfare aspects and carcass quality effects in the transport of cattle, sheep and goats (Part A, B and Livestock and Meat Authority for Meat Research Corporation. Queensland C). Report prepared by Queensland

Livestock and Meat Authority, Australia.

\section{How to cite this article:}

Ambore, B.N., S. Maini, V.R. Patodkar and Borikar, S.T. 2019. Effect of Transportation on Body Weight and Hematology in Goats. Int.J.Curr.Microbiol.App.Sci. 8(07): 947-952. doi: https://doi.org/10.20546/ijcmas.2019.807.114 